ISSN (Print) : :1412-7601

ISSN (Online) : 2654-8712

Volume 6, No.1 Maret 2020

EKONOBIS

http://www.ekonobis.unram.ac.id

\title{
Keragaman Sumber Pembiayaan Usaha Tani Padi Ditinjau Dari Perspektif Islam (Studi Kasus Kecamatan Pringgabaya Lombok Timur)
}

\author{
Muaidy Yasin.
}

Universitas Mataram

ARTICLE INFO

Keywords :

Riba, Salam, financing, farming.

ABSTRACT: This study aims to determine the source of funding for rice farming in
the East Lombok District of Pringabaya and to find out the reasons for farmers
using these financing in terms of an Islamic perspective. This study uses
qualitative methods, data collection methods used in-depth interviews (in-dept-
interview), and documentation. Data analysis through the stages of data
reduction, display data with narrative (verbatim) and draw conclusions. The
results showed that the financing of rice farming in Pringgabaya came from their
own funds, the sale and purchase of salam and nasiah (credit) systems, usury
system loans and from grain traders. Farmers' understanding of the usury system
financing is equated with the trading system of greetings and nasiah (credit).
Because of that, farmers and capital owners (loan sharks) conduct Islamic
business cooperation to avoid usury. The Tuan Guru and Ustazd should give
dakwah material related to mahdhah worship and muamalah.
ABSTRAK: Penelitian ini bertujuan untuk mengetahui sumber pembiayaan usaha tani
padi di Kecamatan Pringabaya Lombok Timur dan untuk mengetahui alasan petani
menggunakan pembiayaan tersebut ditinjau dari perspektif islam. Penelitian ini
menggunakan metode kualitatif, pengumpulan data digunakan metode wawancara
mendalam (in-dept-interview), dan dokumentasi. Analisis data melalui tahapan reduksi
data, display data dengan narasi (verbatim) dan menarik kesimpulan. Hasil penelitian
menunjukkan bahwa pembiayaan usaha tani padi di Pringgabaya berasal dari dana
sendiri, jual beli sistem salam dan nasiah (kredit), pinjaman sistem riba dan dari
pedagang gabah. Pemahaman petani terhadap pembiayaan sistem riba disamakan
dengan sistem jual beli salam dan nasiah (kredit). Oleh kerena itu antara petani dan
pemilik modal (rentenir) melakukan kerjasama usaha secara Islami untuk menghindari
riba. Para Tuan Guru dan Ustazd hendaknya memberikan materi dakwah yang
berkaitan ibadah mahdhah dan muamalah.

Kata Kunci :

Riba, salam, pembiayaan, usaha tani.

Corresponding Author:

Alamat : Program Studi Ekonomi Pembangunan, Fakultas Ekonomi dan Bisnis, Universitas Mataram, Jln. Majapahit No. 62 Mataram.

e-mail: fe.muaidy@ gmail.com 


\section{PENDAHULUAN}

\section{Latar Belakang}

Pembiayaan merupakan salah satu faktor yang sangat penting dalam usaha tani, terutama untuk membeli sarana produksi dan kebutuhan modal kerja lainnya. Namun tidak semua petani memiliki modal yang cukup untuk membiayai usaha taninya terutama bagi petani berlahan sempit dalam rangka untuk meningkatkan produsksi dan pendapatannya. Disisi lain, akses terhadap sumber permodalam formal membutuhkan banyak persyaratan dan agunan yang sering kali tidak dapat dipenuhi oleh petani. Dan oleh pihak perbankan menganggap petani tidak bankable (Pratiwi, 2019, Yoko, 2018), sehingga petani memilih pembiayaan non formal.

Petani di Kecamatan Pringabaya pada umumnya merupakan petani berlahan sempit dilihat dari aspek penguasaan lahan, dimana 33,9 persen menguasai lahan kurang dari 0,50 ha, meskipun termasuk sawah dengan irigasi ternis terluas setelah Kecamatan Sembelia yaitu 1,214 ha (BPS , 2018). Dengan pemilikan lahan yang relatif sempit dan modal usaha tani relatif terbatas, maka aplikasi teknologi pertanian pun juga mengikuti kemampuan petani tersebut. Akibatnya adalah produksi belum optimal, sehingga pendapatan yang diterima oleh petani relatif rendah, dan pemupukan modal usaha tani relatif kecil.

Menyadari kondisi petani yang demikian ini, pemerintah memberikan bantuan modal kepada petani sejak tahun 1969/70 berupa kredit Bimas, KUT tahun 1985, kredit Ketahanan Pangan (KKP), bantuan langsung Masyarakat (BLM) hingga proyek peningkatan Pendapatan petani /nelayak kecil P4K dari tahun 1978 hingga tahun 2005 (Darwis dan Iqbal, 2007) dan bahkan sejak tahun 2007 hingga kini diluncurkan Kredit usaha rakyat untuk UMKM termasuk didalamnya adalah kredit untuk petani.

Bantuan modal dari pemerintah berupa kredit Kredit usaha rakyat untuk petani merupakan bantuan kredit bersubsidi dengan bunga yang rendah, persyaratan dan aturan administrasi yang lebih disederhanakan .Walaupun demikin masih banyak petani yang menggunakan jasa kredit nonformal untuk memenuhi kebutuhan modal usaha taninya, padahal harus membayar bunga pinjaman sebesar 
20-30 persen (Supriatna, 2003).

Penelitian terdahulu menganalisis tentang faktor-faktor yang mempengaruhi petani memilih kredit formal dan nonformal adalah yang dilakukan oleh Pratiwi (2019) dimana faktor pendidikan, lama usaha, bunga dan besar pinjaman berpengaruh sifnifikans terhadap keputusan petani dalam memilih kredit formal dan informal. Sedangkan usia, jumlah anggota keluarga, status lahan dan pendapatan tidak berpengaruh terhadap keputusan petani dalam mamilih kredit formal dan non formal. Selanjutnya penelitian yang dilakukan oleh Yoko (2018) menunjukkan bahwa cos of fun dan pendapatan berpengaruh secara signifikan terhadap permintan kredit di Koperasi Jasa keuangan syariah (KJKS) sedangkan usia petani, luas lahan dan lama menjadi anggota KJKS tidak berpengaruh nyata terhadap permintaan kredit pada KJKS.

Kedua penelitian tersebut menganalisis faktor-faktor yang mempengaruhi petani memilih sumber pembiayaan dari kredit formal dan non formal. Sedangkan penelitian ini difokuskan pada pembiayaan usaha tani yang bersumber dari kredit non formal ditinjau dari perspektif islam. Inilah keterbaruan dari penelitian ini. Berbagai sumber pembiayaan kredit non formal yang diakses oleh petani adalah pedagang beras atau gabah, pedagang input, pinjaman perseorangan, dan pinjaman petani lainnya (Valerina Darwis dan M. Iqbal 2007).

Keterlibatan petani pada pembiayaan non formal merupakan tindakan yang dipilih dari berbagai alternatif yang tersedia untuk menghindarkan diri dari kesulitan pembiayaan yang segera diatasi untuk menghindari resiko usaha taninya. Adapun tujuan penelitian ini adalah untuk mengetahui sumber pembiayaan usaha tani padi petani dan alasan petani memilih pembiayan tersebut dari perspekktif islam.

\section{TINJAUAN PUSTAKA}

1. Teori Voluntaristik dan Teori

\section{Pertukaran Sosial.}

Teori aksi (action theory) dari Talcot Parsons dalam Ritzer (1985:53) berangkat dari asumsi bahwa :

a. Tindakan manusia muncul dari kesadarannya sendiri sebagai subyek dan dari situasi eksternal dalam posisi sebagai obyek

b. Sebagai subyek manusia bertindak untuk mencapai tujuan tertentu.

c. Dalam bertindak manusia menggunakan cara, teknik, 
prosedur, metode serta perangkat yang di perkirakan cocok untuk mencapai tujuan tersebut.

d. Kelangsungan tindakan manusia hanya dibatasi oleh kondisi yang tak dapat diubah dengan sendirinya

e. Manusia memilih, menilai, dan mengevaluasi terhadap tindakan yang akan, sedang dan telah dilakukan

f. Ukuran-ukuran, aturan-aturan atau prinsip-prinsip moral diharapkan timbul pada saat pengambilan keputusan

g. Studi mengenai antar hubungan sosial memerlukan pemakaian teknik penemuan yang bersifat subyektif seperti metode verstehen, imajinasi, sympathetic recontruction atau seakan-akan mengalami sendiri (vicarious exsperience).

Tindakan sosial adalah tindakan individu yang mempunyai makna atau arti subyektif bagi dirinya dan diarahkan kepada tindakan orang lain. Parsons dalam Ritzer (1985:56-57) menyususn unit-unit dasar tindakan sosial sebagai berikut :

1. Adanya individu selaku actor
2. Aktor dipandang sebagai pemburu tujuan tertentu.

3. Aktor mempunyai alternatif cara, alat serta teknik umtuk mencapai tujuannya.

4. Aktor berhadapan dengan sejumlah kondisi situasional yang dapat membatasi tindakanya dalam mencapai tujuan. Kendala tersebut dapat berupa situasi dan kondisi, sebagian ada yang tidak dapat dikendalikan oleh individu.

5. Aktor berada dibawah kendala dari nilai-nilai, norma-norma dan berbagai ide abstrak yang mempengaruhinya dalam memilih dan menentukan tujuan serta tindakan alternatif untuk mencapai tujuan tersebut.

Dengan demikian maka dalam teori aksi (action theory) terdapat sekurangkurangnya lima bagian penting yaitu 1) aktor yaitu pelaku dalam konsepsi Parsons merupakan pelaku individual (pelaku perseorangan), 2) pelaku yang mengejar tujuan (goal), 3) aktor memiliki beberapa alternatif cara atau alat untuk mencapai tujuan (mean), 4) pelaku diatur oleh seperangkat nilai norma, dan ide lainnya (value, norms, and other idea), dan 5) pelaku dihadapkan pada berbagai macam kondisi dan situasi yang dapat mempengaruhi pilihan alat untuk 
mencapai tujuan (condition). Jadi Aktor mengejar tujuan dalam situasi dimana norma-norma mengarahkannya dalam memilih alternatif cara dan alat untuk mencapai tujuan.

Kemampuan aktor inilah yang disebut Parsons sebagai voluntarism yaitu kemampuan individu melakukan tindakan dalam arti menetapkan cara dari sejumlah alternatif yang tersedia dalam rangka mencapai tujuannya. Aktor menurut konsep voluntarisme merupakan pelaku yang aktif dan kreatif serta memiliki kemampuan untuk menilai dan memilih dari alternatif tindakan, walaupun tidak mempunyai kebebasan total namun ia memiliki kemauan bebas dalam memilih berbagai alternatif tindakan.

\section{Dilema Antara Keimanan dan Keinginan}

Perbedaan dasar antara sistem ekonomi konvensional dan sistem ekonomi Islam adalah terletak pada motivasi dan pilihan tindakannya, yaitu bagaimana mendapatkan dan memanfaatkan harta yang didapat dalam kegiatan ekonomi. Menurut Muadz (2005:3), keinginan merupakan penggerak lahirnya sebuah tindakan dan tindakan dapat dimotivasi oleh keimanan (biliefs) dan atau keinginan. Bila motivasi sebuah tindakan didasarkan dan sesuai dengan keimanan, maka motif tindakan tersebut adalah keikhlasan. Tindakan yang ikhlas adalah sebuah kejujuran dan tindakan tersebut tanpa syarat. Tetapi bila motivasi sebuah tindakan didasarkan pada keinginan, maka motiv tindakan tersebut adalah selfinterest.

Tindakan ekonomi tidak dipengaruhi oleh keimanan (agama). la sepenuhnya diatur oleh keinginan dan rasional, dan setiap pilihan tindakan adalah sesuai dengan keinginan-keinginan yang dijustifikasi secara rasional. Ini melahirkan tindakan-tindakan ekonomi yang berdasarkan motif bersyarat yaitu self interest. Mereka percaya bahwa, riba itu tidak dibolehkan, akan tetapi karena keinginannya untuk mendapatkan keuntungan tertentu, ia menjadi pelaku riba. Jadi ketika seseorang sedang melakukan riba maka ketika itu pula dia sedang tidak beriman, dan imannya telah digantikan oleh sesuatu yang lain.

\section{METODOLOGI PENELITIAN}

Penelitian ini merupakan penelitain kualitatif. Penggunaan metode didasarkan pada karakteristik, ruang lingkup dan setting penelitian sesuai dengan kaidah penelitian kualitatif yaitu: 1) data yang diperoleh berupa data verbal, 2) data verbal tersebut mengandung makna. 3) Data tersebut diperoleh langsung dari 
informan melalui pendekatan langsung oleh peneliti kepada informan

Penelitian ini dilaksanakan di dua Desa di Kecamatan Pringgabaya yaitu Desa Kerumut dan Desa Anggaraksa. Penentuan lokasi penelitian didasarkan pada pertimbangan bahwa kedua Desa ini merupakan desa pertanian yaitu sebagian besar penduduknya bekerja sebagai petani dan buruh tani. Subyek atau informan dalam penelitian ini adalah para petani yang menggunakan pembiayaan usaha tani yang berasal dari biaya sendiri, pinjaman dari perseorangan, pembiayaan dengan akad jual-beli dan pinjaman dari pedagang beras dan gabah. Adapun karakteristik informan penelitian adalah :

1. Petani pemilik yang mengunakan modal sendiri tanpa pinjaman (kredit).

2. Petani pemilik yang menggunakan modal sendiri dan sebagian diperoleh dari pinjaman perseorangan.

3. Petani pemilik yang menggunakan modal sendiri dan sebagian pembiayaan dari akad jual beli.

4. Petani pemilik yang memperoleh sebagian pembiayaan dari pedagang gabah/beras.
Selanjutnya, peneliti mulai memasuki daerah penelitian yang dimulai dari Desa Anggaraksa dengan menemui kadus Anggaraksa Timur Bapak Abd Khalid. Informasi yang diperoleh dari Kadus tersebut yang dikaitkan dengan karekteristik petani yang dijadikan sebagai informan, maka informan awal untuk pembiayaan perseorangan adalah A. Nita sekaligus sebagai informan kunci yang memberikan penjelasan tentang praktik pembiayaan usaha tani di Desanya.

Berdasarkan informasi yang diperoleh dari informan awal, ditetapkan informan berikutnya yaitu A. Fir, yang oleh peneliti dapat dipertimbangkan akan memberikan data atau informasi yang lebih lengkap lagi berkaitan fokus penelitian. Data yang diberikan oleh A.Fir selanjutnya dikonfirmasikan lagi dengan informan berikutnya A. Tini, dan ternyata data yang peroleh sama dengan yang diperoleh dari informan sebelumnya yaitu A.Fir dan A. Nita, sehingga dapat dikatakan bahwa data yang diberikan tidak memberikan informasi baru tentang sumber pembiayaan sehingga informasi yang diperoleh mengalami kejenuhan. Metode ini oleh Lincoln dan Guba disebut sebagai serial selection of sampel unit atau dalam istilah Bogdan dan Biklen dinamakan snowball sampling (Sugiyono. 2008 : 55) 
Penentuan informan berikutnya untuk sumber pembiayaan lainnya mengikuti langkah-langkah atau cara yang sama dengan sebelumnya, yaitu penetapan informan berdasarkan karakteristik yang ditetapkan.

Dalam pengumpulan data, digunakan metode observasi secara terus terang dan tersamar lovert observation and covert observation), Sanafiah Faisal dalam Sugiyono (2008; 64-66). Selain metode observasi metode pengumpulan data yang digunakan adalah metode wawancara mendalam (in-dept-interview), yaitu menggali sebanyak-banyaknya informasi atau data dari informan yang berkaitan dengan pembiayaan usaha tani yang digunakan dalam mengelola usaha taninya. Selain kedua teknik tersebut digunakan pula teknik dokumentasi berupa catatan-catatan penting yang berasal dari lembaga maupun perseorangan

Analisis data dalam penelitian ini mengikuti model analisis data interaktif dari Miles dan Hubermans (1992: 15), yaitu analisis yang dilakukan secara terus menerus selama pengumpulan data dilakukan sampai pengumpulan data tuntas dilakukan. Tahap yang dilakukan dalam analisis data adalah :
1. Reduksi data. Data berupa cerita, ungkapan, dan pandangan atau pendapat dari informan apa adanya, kemudian memilih hal-hal pokok yang berkaitan dengan bentuk, proses, akad dalam pembiayaan usaha tani yang dipandu oleh tujuan penelitian ini. selanjutnya data tersebut disusun dalam bentuk verbatim.

2. Penyajian Data (Display Data). Penyajian Data merupakan menyajikan data dalam bentuk naratif (verbatim) prihal bentuk, proses, akad dalam pembiayaan usaha tani yang berasal dari berbagai bersumber pembiayaan ditinjau dari perspektif Islam.

3. Menarik kesimpulan.

Langkah terakhir dalam analisis data adalah menarik kesimpulan. Tindakan petani dalam penggunaan pembiayaan non formal dianalisis dari data tentang pertimbangan dan alasan penggunaan pembiayaan dari berbagai sumber, sehingga ditemukan rasionalitas penggunaan pembiayaan tersebut dari perspektif islam. 


\section{PEMBAHASAN}

\section{Pembiayaan Usaha Tani Dari Dana}

\section{Sendiri}

Biaya usaha tani dengan biaya sendiri merupakan biaya yang bersumber dari pendapatan usaha tani dan luar usaha tani. Pendapatan yang diperoleh dari luar usaha tani memiliki proporsi terbesar dalam pendapatan keluarga, sehingga kebutuhan akan uang tunai pada saat musim tanam mencukupi. Seorang informan berinisial H. FAN yang berasal dari Desa Kerumut adalah seoang petani dan juga sebagai peternak sapi. Luas lahan yang dimiliki 0,30 ha. Dari usaha ternak tersebut diperoleh tambahan pendapatan sekaligus menjadi sumber pembiayaan usaha tani, sebagaimana yang dinyatakan oleh informan berikut ini:

"Sumber biaya usaha tani, kita sisihkan dari hasil kita sehari-hari supaya tidak kita kecumplingan (kesulitan) pada saat kita butuh uang, karena anak-anak sudah kuliah juga butuh uang untuk kuliahnya". "Kalau dari hasil sawah kan tidak cukup, tapi kita cari dari hasil ternak. Karena ternak kan banyak orang butuh, misalnya waktu lebaran atau untuk maulid atau ada orang yang hutang ternak yang dibayar nanti setelah tiga atau empat bulan tergantung dari perjannjian. Kemarin ada orang yang ngambil ternak seharga $R p$ 10.000.0000,yang akan dibayar 3 bulan kemudian. Hasil penjualan ini di pakai untuk beli sapi juga yang kecil-kecil dan setelah empat bulan dia jadi besar dan kita jual lagi. Modal usaha tani informan melalui jual beli ternak baik secara tunai maupun kredit, artinya hasil penjualan ternak baru akan diterima dari pembeli setelah tiga atau empat bulan kemudian, tergantung perjanjian antara penjual dan pembeli.

Informan yang menggunakan modal sendiri adalah berinisial $H$. AZR 60 tahun berasal dari Desa Kerumut, yang memiliki sawah seluas 0,90 ha. Selain bertani pekerjaan informan adalah berdagang sembako di pasar. Lahan usaha tani yang dimiliki tidak semua ditanami padi namun sebagian ditanami sayuran yang bisa dipanen dalam jangka pendek. Produksi padi yang diperoleh informan sebanyak 3 ton dan tidak langsung dijual melainkan diolah dulu jadi beras.

Adanya penanganan pasca panen memberikan nilai tambah melalui proses pengolahan gabah menjadi beras. Nilai tambah tersebut berasal dari rendemen (persentase beras yang diperoleh dari setiap kuintal bagah) yang bisa mencapai 55-60 persen. Artinya setiap satu kuintal gabah diperoleh beras seberat $55-60 \mathrm{~kg}$. 
sebagaimana yang diungkap oleh H.AZR berikut ini :

" Biasanya hasil yang diperoleh di olah dulu jadi beras, dan beras itu dijual dipasar. Jadi ada keuntungan sedikit dibandingkan dengan bila kita jual dalam bentuk gabah. Kalau dijadikan beras selain kita dapat keuntungan di rendemen, dan harga beras yang cukup bagus, juga kita dapat dedaknya yang nilainya bisa nutupi biaya giling sehingga tidak mengurangi hasil yang diperoleh. Untuk satu ton gabah yang diolah jadi beras bisa kita dapat kelebihan $R p$ 750.000,- dibandingkan dengan dijual dalam bentuk gabah".

Proses pemupukan modal oleh informan dilakukan melalui peningkatan nilai tambah padi menjadi beras, sehingga keuntungan yang seharusnya dinikmati oleh pedagang, menjadi tambahan pendapatan bagi informan dari proses peningkatan nilai tambah tersebut. Dengan demikian maka informan tidak mengalami kesulitan atau kekurangan modal untuk setiap musim tanam.

\section{Pembiayaan Usaha Tani dari Pinjaman perseorangan}

Pembiayaan usaha tani dari pinjaman atau perseorangan adalah pinjaman dalam bentuk uang tunai yang diperoleh dari seseorang dengan syarat memberikan uang sejumlah tertentu atas pokok pinjaman sesuai dengan akad pada saat pinjaman dilakukan. Salah satu informan yang menggunakan pembiayaan usaha tani dari kredit perseorangan sistem adalah berinisial A. TINI berumur sekitar 59 tahun yang berasal dari Desa Anggaraksa. Pembiayaan yang diterima adalah dalam bentuk uang tunai dengan syarat membayar bunga atas pinjaman tersebut sebagaimana dinyatakan oleh A.Tini berikut ini :

Pinjaman saya ambil dalam bentuk uang kembali uang dengan bunganya. Memang tidak ada akad yang tertulis tetapi sudah menjadi kebiasaan disisni bila kita minjam uang harus diberi bunganya. Kemarin saya pinjam 1 juta dikembalikan sebanyak 1,3 juta selama tiga bulan.Dan kalau tidak kembali dengan bunganya maka pada waktu mendatang kita sulit tidak dikasi minjam lagi, bahkan kalau bunganya tidak sesuai menurut dia (rentenir) maka kecil kemungkinannya dikasi minjam lagi.

Keterbatasan modal yang dihadapi petani ketikan tanaman dalam masa pertumbuhan (padi berumur 3 minggu), memaksa petani untuk mencari sumber pembiayaan untuk membeli pupuk dan obat perangsang tumbuh yang dibutuhkan 
tanaman padi. sebagaimana yang dinyatakan A.Tini berikut ini:

"Kita sebenarnya sipinate (terpaksa) pinjam di rentenir, karena tidak ada pilihan lain yang lebih murah dan gampang, tidak perlu syarat-syarat ini dan itu. Walaupun ada bank pemerintah prosesnya tidak gampang dan membutuhkan boreg (agunan). Selain syaratnya banyak dan papuk ninenya (mbah putri) juga harus ikut tanda tangan jadinya repot, belum lagi ngurusnya kesana kemari bolak balik kantor bank butuh biaya ojek juga, juga lama realisasinya, kadang-kadang sudah tidak ingat dan butuh uang, baru realisasi. Untuk pinjaman sebesar satu sampai dua juta nyalah (terlalu sedikit) kita kita urus kesana kemari, kecuali butuh puluhan juta baru pinjam di bank.

Informan memilih menggunakan pembiayaan yang berasal dari perseorangan merupakan pilihan yang bersifat terpaksa untuk menghindari resiko hilangnya peluang untuk memperoleh hasil yang optimal. Dalam kredit perseorangan terdapat akad antara peminjam dan pemberi pinjaman meskipun akad tersebut tidak dinyatakan secara tertulis, namun kedua belah pihak sama-sama mengerti tentang konsekwensi dari kesepakatan tersebut.
Menurut Sridadi ( 2009:37) menyatakan wujud kerjasama dapat dinyatakan secara tertulis dan masing-masing menandatangani kesepakatan, dan dapat juga masing-masing pihak sama-sama mengangggukkan kepala sebagai tanda setuju terhadap kesepakatan tersebut.

Informan lain yang menggunakan pinjaman perseorangan adalah A.NITA yang berasal dari Kampung Aikdalem Desa Anggaraksa. Pinjaman dari perseorangan. Informan mengambil pinjaman dari A.Ros selain digunakan untuk pembiayaan usaha tani juga untuk kebutuhan rumah tangga yang lain karena hasil panen yang diperoleh sebelumnya belum dapat memenuhi kebutuhan keluarga hingga musim tanam berikutnya, sebagaimana dinyatakan oleh informan berikut ini:

"Biasanya saya ngambil uang, karena ada saja kebutuhan lain selain untuk beli pupuk ongkos kerja dan lainnya. Pinjaman ini tidak ada akad tertulis berupa perjanjian. Biasanya kita tanya kebiasaan masing-masing orang yang meminjamkan uang untuk per satu jutanya. Karena masing-masing pemilik uang menetapkan besarnya bunga. Untuk pinjaman satu juta rupiah bunganya $R p$ 50.000,- perbulan dan batas pengembaliannya setelah panen. Kalau punya uang dapat dikembalikan kapan 
saja dan yang penting bunganya dibayar setiap bulan. Kalau tidak bisa bayar bunganya setiap bulan maka bunga tersebut akan masuk menambah pokok pinjaman, sehingga pinjaman kita jadi bertambah".

Alasan informan menggunakan pembiayaan dari perseorangan adalah hutang dalam bentuk lainnya memiliki resiko yang sama dengan pinjaman perseorangan terutama beban yang dibayarkan sebagaimana yang diungkap oleh A.Nita berikut ini

"Kalau dihitung-hitung jatuhnya sama saja karena ada potongan harga per kuintalnya, sehingga pinjaman dari sumber mana saja bebannya tetap sama beratnya".

Menurut informan, kelebihan jumlah yang dibayar antara pinjaman perseorangan dengan pinjaman lainnya hampir sama, sehingga informan mengambil pinjaman dari perseorangan. Hal ini berarti informan hanya melihat kedua sumber pembiayaan itu dari kelebihan yang dibayar atau harga yang diterima, sehingga informan menyamakan antara transaksi salam sama dengan riba. sebagaimana tercantum dalam firman Allah surat Al- Baqarah ayat 275
Artinya: Allah Telah menghalalkan jual beli dan mengharamkan riba. (Q.S.2.275)

Jadi ketika seseorang sedang melakukan praktik riba, maka ketika itu pula ia sedang tidak beriman. Keimanannya sudah tidak lagi berfungsi sebagai pengarah dan pengatur tindakan, dan fungsinya telah diganti oleh keinginan-keinginan dengan rasio sebagai instrumennya. Dengan kata lain keimanannya telah berada dalam ranah kognitif dan tidak lagi berada pada ranak praktis. Tindakan ini oleh Abdul Gani (2005: 64) disebut dengan istilah splits of personality atau splits of sprituality.

\section{Pembiayaan Bersumber Dari Pedagang}

\section{Pengumpul Gabah.}

Para petani selain memperoleh pembiayaan dari perseorangan, juga dapat diperoleh dari pedagang pengumpul gabah. Pinjaman ini diperoleh melalui akad jual beli gabah yang pembayarannya dilakukan secara tunai namum penyerahan barangnya dilakukan setelah panen. Jual beli yang pembayarannya dilakukan secara tunai saat transaksi dan barangnya diserahkan kemudian disebut dengan jual beli salam. (Al Mushlih, 2004: 119).

Peraktik pembiayaan yang bersumber dari jual beli salam dilakukan 
oleh informan berinisial A. INAH yang barasal dari Desa Kerumut memiliki sawah seluas 0,50 Informan membutuhkan tambahan modal usaha tani mendatangi seseorang yang berinisial A.Fat, bermaksud untuk menjual padi sebanyak 6 kuintal sebagaimana dinyatakan oleh A. Inah berikut ini :

Seperti saya telah katakan tadi, kalau dari hasil sawah diambilkan semua kebutuhan kita, untuk rokok makan dan sebagainya tidak cukup. Tiang kemarin menjual padi sama Amak Fat 6 kuintal harga Rp 325.000 untuk satu kuintal, setelah panen baru diterima gabahnya. Jadi kita bilang sama dia "Tiang jual pade 6 kuintal aji telungatus selae jemak uah matak terima gabahna"(artinya saya jual padi harga $R p$ 325.000,-nanti setelah panen diterima gabahnya). Kalau dijual secara tunai harganya $R p$ 340.000,-

Praktik jual beli gabah seperti ini sudah umum dilakukan saat petani membutuhkan tambahan modal atau untuk kebutuhan keluarga seperti untuk bayar SPP anaknya atau kebutuhan lain yang sangat mendesak dalam keluarga. Jual beli gabah seperti ini sesungguhnya kurang menguntungkan petani karena menerima harga lebih rendah dibandingkan dengan harga pasar. Prektik jual beli seperti ini dalam islam disebut dengan istilah penjualan sistem salam dan dibolehkan secara islam

Diibolehkannya jual beli sistem salam (akad salam) ini, bertolak dari hadis Rasulullah dari Ibn Abbas ra berkata Rasulullah setibanya di madinah, menjumpai orang-orang melakukan pembayaran terlebih dahulu untuk harga buah-buahan. Rasulullah saw bersabda : yang diriwayatkan oleh Jama'ah dalam Yusuf Qardhawi, 2007: 378 menyatakan bahwa :

"Barang siapa melakukan pembayaran di depan, hendaknya untuk suatu barang dengan takaran tertentu, timbangan tertentu dan untuk waktu tertentu".

Bila dilihat dari kaidah fiqih yang menyatakan "hukum pokok dari segala rupa perkara atau urusan ialah kebolehannya sehingga datang dalil yang menunjukkan kepada haramnya atau peniadaan hukum kebolehannya" (Bisri Affandi, 2010). Sehingga Jumhur (mayoritas) ulama membolehkan, karena hukum asal semua aktifitas boleh, dan tidak ada dalil yang mengharamkan praktik ini dan tidak ada kesamaan dengan riba. Penjual boleh saja menaikkan harga dagangannya karena pertimbangan pertimbangan tertentu yang ia lihat, selama tidak sampai kepada 
batas mementingkan diri sendiri (self interest) dan tindakan aniaya. Dalam kaidah fiqih disebutkan la darar wa la dirara yang mengandung arti dilarang menimbulkan bahaya atau kerugian bagi orang lain yaitu perbuatan yang menguntungkan diri sendiri namum merugikan orang lain dilarang. Bila sampai keadaannya demikian maka hukumnya adalah haram.

Adapun syarat-syarat akad salam adalah sebagai berikut ( Abdurrhman asSa'di , 2008):

a. yang sudah Barang jaminan tersebut syarat-syaratnya jelas.

b. Ukuran barang harus sesuai dengan uang yang dibayarkan.

c. Ukurannya jelas baik berupa takaran, timbangan.

d. Barang jaminan tersebut tetap berada ditempatnya.

e. Uang pembayaran (pinjaman) diserahkan pada waktu aka

f. Barang tersebut masih dalam jaminan, jika menjaminkan jaminan barang

g. jelas ada tidak dibolehkan.

Sebagai acuan dasar dibolehkannya akad salam adalah firman Allah swt dalam surat al-Baqarah :

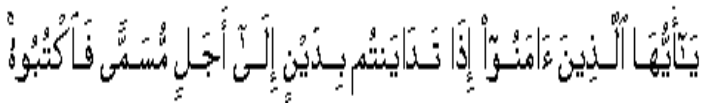

Artinya: Hai orang-orang yang beriman, apabila kamu bermu'amalah ${ }^{[179]}$ tidak secara tunai untuk waktu yang ditentukan, hendaklah kamu menuliskannya (Q.S.2.282).

Dalam firman Allah swt surat alBaqarah 282 dan Hadist Rasulullah saw, disebutkan bahwa dalam akad salam diperlukan akad (perjanjian) secara tertulis terkait dengan takaran, timbangan serta, batas waktu pelunasan. Hal ini dimaksudkan untuk menghindari kemungkinan terjadi perselisihan dan penipuan yang merugikan salah satu pihak baik penjual maupun pembeli. Oleh karena itu, Yusuf Qardhawi (2007: 379) menyatakan bahwa dalam akad salam yang paling aman adalah hendaknya tidak disyaratkan tanaman tertentu, atau ladang tertentu, namun ditentukan takaran dan timbangannya saja dari jenis barang tersebut. Jika dalam transaksi itu terdapat unsur-unsur pemerasan sehingga terpaksa menerimanya, maka ketika itu pula haram hukumnya.

\section{Pembiayaan Bersumber Dari Pedagang}

\section{Saprodi}

Selain pembiayaan yang berasal dari jual beli sistem salam, juga terdapat informan yang menggunakan pembiayaan dengan jual beli yang pembayarannya dilakukan setelah panen. Jual beli ini 
disebut jual beli kredit yang pembayarannya dilakukan secara cicilan atau sekali gus saat masa pelunasan dan dalam fiqih muamalah disebut dengan istilah jual beli nasi'ah (Al-Mushlih, 2004:119).

Pembiayaan ini dilakukan oleh informan berinisial A. MSDR berasal dari Desa Anggaraksa. ketika modal sendiri tidak cukup untuk membeli sarana produksi seperti pupuk dan obat-obatan sebagaimana dinyatakan oleh informan berikut ini:

Untuk membeli bibit, pupuk dan lainnya biaya berasal dari biaya sendiri, dan kalau tidak cukup kita ngambil hutang rabuk dengan cara nempo. Memang saya telah mengajukan kredit KUR di bank BRI pohgading dengan jaminan BPKB motor, tapi hingga saat dibutuhkan uang tersebut belum keluar, dan akhirnya nempo rabuk yang nanti di lunasi kalau sudah panen. Saya hutang pupuk urea sebanyak $3 \mathrm{kw}$ dan TSP $1 \mathrm{kw}$. Harganya lebih tinggi dari harga kontan namun selisihnya tidak banyak kalau kontan harganya Rp 230.000, per kw untuk urea sedangkan harga kredit Rp240.000,- dan untuk TSP sama harganya dengan pupuk Urea harga kredit Rp240.000,-dan harga kontan Rp230.000,Terdapat perbedaan harga kredit dan harga tunai sebesar Rp 10.000,- Bila jatuh tempo pelunasan hutang jual beli kredit tiba dan informan tidak dapat melunasi hutangnya, maka kelebihan harga tersebut akan menjadi dua kali lipat sehingga hutangnya menjadi Rp 250.000/ kw. Kelebihan pembayaran karena melampaui jatuh tempo pembayaran termasuk riba nasiah yang hukumnya haram sebagaimana dinyatakan oleh informan berikut ini.

Ya pasti ada, jadi nya hutang kita senilai total harga pupuk secara kredit (nempo). Karena tidak sanggup bayar maka diberikan waktu hingga musim tanam berikutnya ditambah kelebihan harga nempo per kuintalnya. Selisih harga nempo Rp 10.000,- jadi kita bayar setelah musim tanam kedua jadinya $R p$ $250.000 / k w$.

Dengan demikian maka pembiayaan kredit akan berubah menjadi pembiayaan riba karena panambahan sebesar selisih harga kredit (nempo) akibat penundaan pembayaran. Penambahan ini termasuk dalam kriteria riba nasi'ah yaitu riba karena tenggang waktu. Jadi riba nasi'ah adalah tambahan atas pokok pinjaman yang dibayarkan sesuai dengan lamanya tenggang waktu peminjaman yang diberikan. 
Keterbatasan modal yang dialami oleh petani merupakan kenyataan yang tidak dapat dihindari, sehingga petani menentukan suatu tindakan yang dipilih dari berbagai alternatif yang tersedia untuk menghindari kegagalan panen atau turunya output yang diperoleh. Ritzer (1985:57), menyatakan aktor mengejar tujuan dalam situasi di mana normanorma mengarahkannya dalam memilih alternatif cara dan alat untuk mencapai tujuan. Norma-norma tersebut tidak menetapkan pilihannya terhadap cara atau alat tetapi ditentukan oleh kemampuan aktor untuk memilih. Kemampuan itulah yang disebur Parsons sebagai voluntarism yaitu kemampuan undividu untuk melakukan tindakan dalam arti menetapkan cara atau alat dari sejumlah alternatif yang tersedia dalam rangka mencapai tujuannya.

\section{Pembiayaan Bersumber Pedagang Beras} (Gabah).

Pinjaman dari pedagang beras ini, dapat berupa uang tunai maupun sarana produksi dan lainnya. Pinjaman dalam bentuk uang tunai ini dapat digunakan oleh petani untuk membeli sarana produksi seperti pupuk dan obat-obatan dan untuk kebutuhan lainnya seperti kebutuhan uang sekolah bagi anak-anak yang dapat dilunasi atau dikembalikan setelah panen tanpa dikenakan bunga atas pokok pinjaman tersebut. Demikian juga hutang dalam bentuk kebutuhan konsumsi keluarga sehari-hari seperti beras, sarana produksi seperti pupuk, obat-obatan, dan lainnya, dapat dibayar kembali setelah panen.

Seorang Informan berinisial A.Hani, umur 62 tahun lahir di Desa Kerumut. Modal untuk usaha tani berasal dari sebagian dari modal sendiri dan sebagian sisanya dipinjam dalam bentuk barang dari pedagang pengumpul di desa Apitaik tetangga desa tempat tinggalnya berinisial A.Hilmi. Sebagaimana yang dinyatakan informan berikut ini :

Untuk biaya-biaya usaha tani memang ada yang bersumber dari dana sendiri dan ada juga dana kita pinjaman. Untuk dana pinjaman kita biasanya ngutang dari tetangga yang punya uang, tapi sekarang kita ngutang bibit, pupuk dan lainnya dari saudagar, bahkan kalau tidak ada sangu (bekal hidup berupa beras) bisa juga kita ngutang sama dia asal hasil produksi kita jual ke dia. Pembayaran untuk semua hutang kita itu ditotal dan dikurangi dengan nilai produksi padi yang kita jual ke saudagar tersebut. Dibandingkan dengan kalau kita pinjam uang untuk beli pupuk, bibit dan untuk ongkos-ongkos yang lain jatuhnya 
berat, karena selain bunganya besar juga tidak boleh menurut agama hukumnya haram karena termasuk riba.

Pinjaman yang diberikan oleh pedagang kepada informan selain sarana produksi juga menghutang beras untuk konsumsi keluarga sebanyak 1(satu) kuintal. Semua pinjaman informan berjumlah 2 (dua) juta rupiah. Pinjaman ini tidak memiliki syarat-syarat tertentu yang harus dipenuhi seperti membayar bunga atau sangsi membayar harga lebih tinggi bila tidak dapat membayar pada saat jatuh tempo. Pinjaman ini sematamata dihajatkan untuk saling membantu satu sama lain ketika menghadapi kesulitan uang tunai. Total nilai pinjaman informan (pupuk,obat-obatan, beras) yang akan dibayar setelah panen sebagaimana dipaparkan informan berikut ini :

Total pinjaman kita sekitar 2 juta karena hampir semua biaya usaha tani ini dan kebutuhan beras saya hutang kan karena tidak ada konsekwensi yang memberatkan dari segi kelebihan dan potongan harga untuk barang (gabah) kita atau dilebihkan harga beras atau pupuk karena kita ngutang. Hanya saja ketika panen dia minta keikhlasan kita untuk dipotong sebanyak $R p \quad 5.000$ perkuintalnya. Semuanya ini didasarkan atas kesepakatan dan keihlasan kita dan kalau sekiranya kita tidak setuju untuk tidak dipotong tidak apa-apa. Inilah rasa terimakssih kita yang dibantu ketika kita butuh dana untuk usaha tani. Kalau misalnya dari hasil panen sekarang tidak cukup untuk membayar hutang kita karena tanaman rusak sehingga gagal panen, tidak ada sangsi apapun bahkan untuk biaya musin tanam berikutnya kita dikasih minjam lagi untuk pembelian pupuk atau beras untuk kebutuhan makan sehari-hari, pokoknya secukupnya kebutuhan kita diberikan.

Pinjaman dari pedagang Gabah ini tidak ada perjanjian secara tertulis yang harus ditandatangani namun pada saat transaksi berlangsung informan diberitahu bahwa dalam catatan pedagang tersebut total pinjamannya berjumlah 2 juta rupiah dan informan mengiyakanyang nantinya di informasikan kepada istrinya tentang total pinjamannya tersebut. Dari aspek hukum perdata pasal 1320 mengenai syarat syahnya perjanjian dinyatakan bahwa syarat sahnya suatu perjanjian adalah adanya kesepakatan pihak-pihak yang mengikatkan dirinya, yang diwujudkan dengan ungkapan setuju dari kedua belah pihak, atau menganggukkan kepala sebagai tanda setuju atas kesepakatan yang dibuat kedua belah pihak ( Sridadi. 2009 : 37). 
Informan yang menggunakan pinjaman dari Pedagang Beras adalah $\mathrm{A}$. Gop umur 39 tahun, di Desa Kerumut. Sawah yang dimiliki swluas 1,25 ha. Pembiayaan usaha taninya sebagian berasal dari pedagang dan sebagian dari modal sendiri. Bentuk pinjaman yang diberikan oleh pengusaha beras tersebut adalah dalam bentuk uang dan barang. Pinjaman dalam bentuk uang digunkan untuk membiayai olah tanah dan penanaman, sedangkan dalam bentuk barang seperti pupuk dan obat-obatan sebagaimana dinyatakan oleh informan :

Untuk biaya olah lahan dan panenaman saya ambil pinjaman $R p$ 2.000.000,- sekaligus, karena biaya olah lahan sebesar $R p$ 1.200.000,- dan biaya tanam sebanyak $R p$ 850.000,- Setelah tanaman berumur menjelang satu bulan saatnya untuk di pupuk, maka kembali saya berutang sebanyak sebanyak 4.5 kuintal terdiri atas pupuk urea 2 kw, pelangi 1 kuintal, pupuk poska $1 \mathrm{kw}$ dan TSP 0,50 kw. Untuk pemupukan kedua lebih sedikit digunakan pupuk yaitu 3 kuintal terdiri atas urea $1 \mathrm{kw}$, pelangi $1 \mathrm{kw}$, ponska 0,50 kw dan TSP 0,5 kw. Semua biaya-biaya ini dipinjam kepada pengusaha padi tersebut

Semua pinjaman tersebut tidak disertai dengan syarat tertentu misalnya bunga pinjaman dan tambahan atau penurunan harga saprodi yang dihutang (kredit) tersebut. Hal ini terjadi karena keeratan hubungn yang sudah terjalin sejak lama dan kedua belah pihak sudah saling percaya sehingga terjalin hubungan simbiosis untuk saling membantu satu sama lain. Hal ini dinyatakan oleh informan berikut ini.

"Karena sudah lama berhubungan, maka sebelumnya dia sudah katakan, nanti saya yang biayai padi yang akan ditanam ini. Jadi ketika kita datangi untuk minta pinjaman, dia sudah tahu dan langsung menanyakan kapan mau mulai tanam padi. Dan seketika pula kita sebutkan kebutuhan kita untuk biaya nenggala (bajak tanah) dan tanam padi. Sistem bayar didepan dengan harga lebih rendah sudah tidak ada lagi disini, karena sudah banyak tempat pinjam yang yang tidak pakai bunga, gampang dan murah".

Hanya saja semua hasil panen padi dijual kepada pedagang pengumpul tersebut yang harganya dihitung sesuai harga pasar yang berlaku. Dan pada saat penimbangan berlangsung dipotong $\mathrm{Rp}$ 5000,- setiap kuintalnya sesuai dengan yang disepakati pada awal akad pinjaman seperti penuturan informan berikut ini.

"Tidak ada syarat-syarat misalnya bunga atau denda bila kita terlambat 
bayar. Tapi ada ganjelan (potongan harga) sebesar $R p$ 5.000,- untuk setip kuintal padi yang kita jual kepadanya dan dipotong nanti ketika pembayaran hasil panen. Dan Jika kita tidak mampu bayar karena gagal panen akibat hama atau penyakit, kita masih dikasi minjam lagi untuk musim tanam berikutnya tanpa ada denda, asal produk dijual kepadanya".

Adanya keringanan dan kemudahan yang diterima oleh petani atas pelunasan pinjamannya dan keikhlasan pedagang beras atas nilai uang yang harus diterimanya sekarang, adalah satu bentuk tindakan keberterimaan yang dilakukan tanpa syarat atau tanpa motif. Dalam istilah sehari-hari, tindakan tersebut di istilahkan tindakan tanpa pamrih, atau kepamrihan yaitu sesuatu yang dilakakukan tanpa mengharap balasan apapun dari orang lain kecuali sematamata mengharap keredhaan dari Allah Swt.

Allah Swt berfirman dalam surat AlFatir sebagai berikut ;

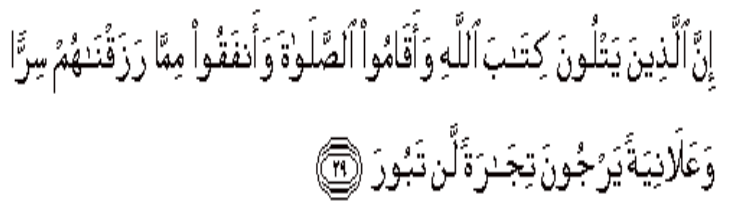

Artinya : Sesungguhnya orang-orang yang selalu membaca kitab Allah dan mendirikan shalat dan menafkahkan sebahagian dari rezki yang Kami anugerahkan kepada mereka dengan diam-diam dan terang-terangan, mereka itu mengharapkan perniagaan yang tidak akan merugi (Q.S. 35:29)

Tindakan yang dilakukan oleh pedagang tersebut tidak semata mata karena kedekatan hubungan kekeluargaan diantara mereka, namun dilakukan dengan niat saling membantu dan saling membutuhkan. Petani membutuhkan bantuan dana sedangkan pedagang menginginkan adanya kontinuitas komodity yang diusahakan berlangsung sepanjang musim panen. Kerjasama antara petani dan pedagang ini akan membawa dampak terhadap kontinuitas komodity dan kepastian pasar output petani sehingga melahirkan keuntungan pada kedua belah pihak.

\section{KESIMPULAN DAN SARAN.}

\section{Kesimpulan}

1. Sumber pembiayaan usaha tani padi di Kecamatan Pringgabaya berasal dari dana sendiri, pembiayaan sistem salam dan kredit, pembiayaan dari pedagang gabah dan pembiayaan perseorangan.

2. Pembiayaan yang bersumber dari dana sendiri, sistem salam, kredit dan dari pedagang beras termasuk dalam pembiayaan yang islami, sedangkan pembiayaan dari perseorangan 
termasuk pembiayaan tidak islami karena termasuk riba yang diharamkan

3. Pemahaman petani terhadap pembiayaan dari perseorangan dengan sistem riba disamakan dengan sistem salam dan kredit karena dilihat dari besarnya perbedaan harga dari kedua sistem tersebut tanpa melihat dari akad dari kedua sistem pembiayaan tersebut.

4. Pembiayaan sistem salam dan kredit tidak melanggar nilai-nilai Islam karena dalam akad dinyatakan secara tegas jenis barang, harga, jumlahnya, dan kapan diterima atau diserahkan sehingga tidak ada yang dirugikan. Hal ini sesuai dengan surat Al-Baqarah Ayat 282 .

Saran

1. Praktik riba telah menjadi prilaku di masyarakat dan tindakan tersebut bertentangan dengan syariat Islam yang dianutnya. Oleh karena itu antara petani dan pemilik modal (rentenir) melakukan kerjasama usaha secara Islami dengan sistem mudharabah yang pembagian keuntungannya sesuai dengan ketentuan yang disepakati bersama.

2. Kekurangan modal bagi petani berlangsung setiap kali musim tanam. Oleh karena itu, sebagai bentuk tanggungjawab pemerintah dalam memakmurkan rakyatnya, harus difasilitasi terbentuknya lembaga keuangan yang operasionalnya sesuai dengan ketentuan syari'ah.

3.Dalam rangka pembinaan umat, hendaknya para Tuan Guru dan Ustazd memberikan materi pengajian yang berkaitan dengan muamalah di samping materi yang berkaitan dengan ibadah mahdhah.

\section{DAFTAR PUSTAKA}

Ade Supriatna, 2003. Aksesibilitas Petani Kecil pada Sumber Kredit Pertanian di Tingkat Desa : Studi Kasus Petani Padi di Nusa Tenggara Barat, Jurnal Balai Besar Pengkajian dan Pengembangan Teknologi Pertanian, Bogor

Al-Muslih Abdullah dan Shalah Ash-Shawi, 2004. Fikih Ekonomi Keuangan Islam, Ed.I, (Diterjemahkan oleh: Abu Umar Basyir), Jakarta, Darur Haq. 
Aminuddin, 2003. Tujuan, Strstegi, dan Model dalam penelitian kualitatif dalam Metodologi Penelitian Kualitatif. Tinjauan Teoritis dan Praktis (Bakri ed), Universitas Islam Malang dan Visi Press. Malang

Anwar Syamsul, 2007. Bunga dan Riba dalam Perspektif Hukum Islam, Jurnal Tarjih dan Tajdid, Edisi Ke 9, Zulhijah 1427 H/ Januari 2007 M.

As-Sa'di Syekh Abdurrahman, 2008. Fiqh Jual Beli, Panduan Praktis Bisnis Sysriah, Jakarta : Senayan Publishing.

Coleman, James. S. Thomas J. Fararo, 1992. Rational Choice Theory, Advocacy and Criticue, 7 Issues in Sociological Theory, London. International Education and professional piblisher.

Darwis \& Iqbal (2010) .Keragaan Pemanfaatan Dan Sumber Pinjaman Usaha Tani Padi Sawah. Pusat Social Ekonomi Dan Kebijakan http://pse.litbang.pertanian.go.id/ind/pdffiles/Pros_2012_02E_MP_Valeriana2.pdf

Ghani, Muhammad Abdul. 2005. The Spirituality in Bussines. Pencerahan Hati Bagi Pelaku Usaha. Jakarta, Pena Pundi Aksara

Hakim, Abdul, 2007. Pilihan Strategi Masyarakat Pedesaan Dalam menghadapi Krisis (sebuah perspektif Sosiologis). Jurnal Ilmiah Administrasi Publik, Fakultas Ilmu Administrasi, Malang.

Hamidi, 2008. Metode Penelitian Kualitatif, Pendekatan Praktis Penulisan Proposal dan Laporan Penelitian, Malang, UMM Press

Hastuti, Endang Lestari dan Supadi, 2002. Aksessibilitas Masyarakat terhadap Kelembagaan Pembiayaan Pertanian di Pedesaan di Jawa Barat dan Nusa Tenggara Barat. Jurnal Pusat Penelitian dan Pengambangan Sosial Ekonomi Pertanian, Bogor

Muslich H. Ahmad Wardi, 2010, Fiqh Muamalat, Ed 1, Jakarta, Amzah.

Muazd,2005, Telaah Ekonomi Islam. Disampaikan dalam pembukaa Kantor Cabang Bank NTB Syariah Selong. Tidak di Publikasikan 
Pertiwi, WN (Ed) 2014. Analisis Pengembalian Kredit Ketahanan Pangan dan Energi (KKP-E) Petani Padi di Kabupaten Kudus Jurnal Riset Ekonomi Pembangunan Volume 3 No 1.

Pertiwi , Irham \& Masyhuri (2019). Analisis Pengembalian Kredit Ketahanan Pangan Dan Energi (Kkp-E) Petani Padi Di Kabupaten Kudus. Jurnal REP Volume 3 Nomor 1 (Riset Ekonomi Pembangunan) http://jurnal.untidar.ac.id/index.php/REP

Poloma. Margareth. M, 1987. Sosiologi Kontemporer, Ed.2. Jakarta, CV Rajawali.

Qardawi Yusuf, 2007. Halal dan Haram dalam Islam, Ed 4, Solo, Era Intermedia.

Ritzer George, 1985. Sosiologi Ilmu Pengetahuan Berperan Ganda, Jakarta, CV Rajawali.

Ritzer George, Douglas J. Goodman, 2004. Teori Sosiologi Modern. Ed 1. Jakarta. Prenada Media.

Sridadi, Ahmad Rizki, 2009. Aspek Hukum Dalam Bisnis. Airlangga University Press. Surabaya.

Sugiyono, 2007. Metode Penelitian Bisnis, Alfabeta. Bandung. 2008. Memahami Penelitian Kualitatif, Alfabeta. Bandung.

Yoko Budi, Prayoga A, 2019. Akses dan Persepsi Petani terhadap Pembiayaan Pertanian Mikro Syariah : Studi di Kabupaten Lampung Tengah, Journal of Halal Product and Research Volume 2. Nomor 1.

Yoko.2016.Analisis permintaan pembiayaan pertanian syariah untuk usaha tani padi dikabupaten lampung tengah.Jurnal bisnis tani agribisnis universitas teuku umar. http://jurnal.utu.ac.id/jbtani/article/download/532/444 